\title{
Globe
}

Revue internationale d'études québécoises

\section{Damien-Claude Bélanger, Sophie Coupal et Michel Ducharme (dir.) : Les idées en mouvement : perspectives en histoire intellectuelle et culturelle du Canada. Québec, Presses de l’Université Laval, coll. «Cultures québécoises », 2004}

K. L.

Volume 7, numéro 2, 2004

URI : https://id.erudit.org/iderudit/1000872ar

DOI : https://doi.org/10.7202/1000872ar

Aller au sommaire du numéro

Éditeur(s)

Globe, Revue internationale d'études québécoises

ISSN

1481-5869 (imprimé)

1923-8231 (numérique)

Découvrir la revue

Citer ce compte rendu

L., K. (2004). Compte rendu de [Damien-Claude Bélanger, Sophie Coupal et Michel Ducharme (dir.) : Les idées en mouvement : perspectives en histoire intellectuelle et culturelle du Canada. Québec, Presses de l'Université Laval, coll. "Cultures québécoises », 2004]. Globe, 7(2), 213-213.

https://doi.org/10.7202/1000872ar d'utilisation que vous pouvez consulter en ligne.

https://apropos.erudit.org/fr/usagers/politique-dutilisation/ 
minutieuse de toute l'époque ainsi qu'un nombre important de lettres de Gauvreau à divers destinataires consignés en appendice, lettres éclairant notamment sa pensée sur l'art et ses épisodes d'internement. Cette édition critique, qui convoque toute la documentation existante sur le sujet, constitue une excellente porte d'entrée pour aborder l'automatisme au Québec.

K.L.

\section{Damien-Claude Bélanger, Sophie Coupal et Michel Ducharme (dir.)}

Les idées en mouvement: perspectives en bistoire intellectuelle et culturelle du Canada. Québec, Presses de l'Université Laval, coll. "Cultures québécoises ", 2004.

Depuis une décennie, de Ronald Rudin à Jocelyn Létourneau, d'une remise en question à l'autre, le champ de l'histoire explore des hypothèses et des pistes qui se sont révélées des plus stimulantes, qu'on en accepte les prémisses et les postures, qu'on les discute ou même qu'on cherche à les réfuter. Dans cette foulée, un collectif récent, Les idées en mouvement: perspectives en bistoire intellectuelle et culturelle du Canada, publié sous la direction de Damien-Claude Bélanger, Sophie Coupal et Michel Ducharme, fait ainsi le point de manière fort utile sur la faveur actuelle au Canada de l'histoire intellectuelle et culturelle. Réunissant des voix aussi diverses que celles de Ramsey Cook, Pierre Trépanier, Heather Murray, Sylvie Lacombe, Yvan Lamonde et plusieurs autres, l'ouvrage essaie notamment de penser, sur le plan historiographique, une possible alliance des champs culturel et intellectuel, sans valoriser l'un au détriment de l'autre, et offre au lecteur nombre de réflexions d'ordre méthodologique qui pourront baliser la recherche future.

K.L. 